\title{
28 Research Square \\ The Role of Gold as Haven or Diversifier Invesment in Indonesia
}

\section{Agung Nusantara}

Stikubank University: Universitas Stikubank

\section{Sri Nawatmi}

Stikubank University: Universitas Stikubank

\section{Agus Budi Santosa}

Stikubank University: Universitas Stikubank

\section{Bambang Sudiyatno ( $\sim$ bsud@edu.unisbank.ac.id)}

Stikubank University: Universitas Stikubank https://orcid.org/0000-0002-6428-3615

\section{Research}

Keywords: Gold, haven, Diversifier investment, Cross-correlation, Forecasting, Indonesia

Posted Date: August 18th, 2021

DOI: https://doi.org/10.21203/rs.3.rs-789580/v1

License: (c) (i) This work is licensed under a Creative Commons Attribution 4.0 International License. Read Full License 


\section{Abstract}

The objective of this study is to analyzes gold ownership in Indonesia related to the treatment of gold whether gold is used as a haven or diversifier investment. To determine gold as a haven or diversifier investment, the research method used is the general correlation method and cross correlation. The variables used in this study are gold price variables, investment interest rates, LQ 45, exchange rates and inflation, using data from 2018.1 to 2020.10. The results show that gold in Indonesia is more of a haven than a diversifier investment. Based on expectations of gold prices for the next year, it shows that the relationship between gold prices - interest rates and gold prices - exchange rates is a strong complementarity, while the relationship between gold prices and LQ45 is a very strong substitution or diversification.

\section{Introduction}

Covid-19 which has developed into a pandemic in various countries has caused many investors to have high concerns because the effects of the pandemic have made the change from a health crisis to an economic crisis. The existence of the world economic crisis has caused many people to think about saving their assets so that their value does not decrease. For this reason, they are thinking about replacing assets that tend to decline in value with other assets such as gold (for example).

Gold is a precious metal that attracts the interest of various circles, not only regarding its beauty but also the value of gold itself. Gold can be used as jewelry, it can also be used as currency, input in the industrial sector, as well as an investment tool.

In the discussion about gold as an asset, the debate actually includes two terms, namely wether gold acts more as a safe haven asset or as a diversifier investment. In this study, the two terms are matched with a store of value as a safe haven and investment tool as a diversifier investment.

A store of value is an asset that is able to maintain the value it contains, not easy to depreciate. Gold and other precious metals are good stores of value because they have a long shelf life. A country's currency must be a reasonable store of value for its economy to function smoothly. In other words, an object can be used as a store of value if the object has a relatively stable value and is less likely to depreciate. In the case of gold, the price of gold is relatively stable, at least until 2010 qualified as a store of value. However, in the following period, there were relatively high fluctuations, so gold became too risky to be considered a store of value. Therefore, the idea of using gold as an investment tool began to emerge.

The results of Fernando's research (2017) state that one of the reasons for the increasing interest in gold investment is the perceived risk in the economy. Risk management is very important in today's era which is full of uncertainty in terms of economy, finance and politics. At the same time, increasing correlations between traditional diversification roles make diversification more difficult. In Sweden, gold is a great diversification in the equity portfolio. So, according to Fernando, gold is an investment tool, while according to Ritholtz (2016) gold is not an investment tool but gold is a store of value and currency.

Historically gold has been seen as more attractive investment than stocks and bonds or other assets classes, not only for the positive returns but also as safe haven in time of difficulty (Kovinski, 2014).

\section{Conceptual Framework}


In the discussion about gold as an asset, the debate actually includes two terms, namely whether gold acts more as a safe haven asset or as an investment diversifier. According to Flavin, Morley and Panapolou (2014), safe havens are assets that have low market risk and are liquid, which are used by investors to overcome fears of losses in the capital market. Technically, the meaning of safe haven is if the correlation between an asset and other assets is negative or zero, especially in market conditions full of uncertainty (Baur and Lucey, 2010). The term diversification has a general meaning, namely the efforts of investors to manage risk by holding several portfolios.

Several studies on gold and other assets, have mixed results. Faugere and van Erlach (2006) and Lucey, Tully and Poti (2006), Shakil, et.al. (2017), and de Cnijf (2019) conclude that gold acts more as a hedging tool or a safe haven, when the economy is in a state of uncertainty until it penetrates the stock market. Faugere and van Erlach (2006) compare the price of gold with stock prices, exchange rates and inflation. According to Faugere and van Erlach (2006) gold in normal conditions has various roles, but in turnmoil conditions, gold is more visible in its role as a hedging tool or acts as a safe haven. De Cnijf (2019) argues that the belief that gold acts as a safe haven does not apply when the economic and stock market turmoil is extreme so that the ambiguity of gold's role is very obvious.

Similar studies with different results were conducted by Ibrahim and Baharom (2012), and Robiyanto (2018). They have a general conclusion that gold is able to make a significant contribution as an investment tool when the economy leads to uncertainty to penetrate the capital market conditions. In line with this conclusion, according to Robiyanto (2018), the role of gold in the Indonesian and Malaysian economies illustrates the diversification of investment, both in government and corporate bonds, because stocks themselves have shown hedge properties with the magnitude of the phenomenon of comovement with related factors.

Agha et al (2015) state that there are two ways to invest in gold, namely by investing in physical gold and paper gold. They tested the gold status in the Islamic perspective, qualitative research method, tested operational, contemporary application and the issue of Sharia compliance. Based on Shariah compliance, out of seven banks, only one bank offers Shariah-approved gold savings accounts. Recent trends show that Malaysians are increasingly turning to gold investment as one of the sharia-compliant mechanisms to protect wealth.

Toraman et al (2011) used data from June 1992 - March 2010 namely data on oil prices, USA Exchange rate, USA inflation rate, USA real interest rate. The results stated that the highest correlation was found between gold prices and the USA exchange rate, where the relationship between the two was negative. The second highest correlation is between the gold price and the oil price (positive correlation).

\section{Method}

In an effort to determine whether gold assets act as a safe haven or diversifier investment in Indonesia, the calculation and analysis process is designed as follows:

Stage I: Identify the Relationship between Gold Price Variables and Comparative Price Variables.

This stage is an attempt to determine the pattern of movement between the gold price variable and other variables identified as variables related to diversifier investment or safe haven activities. Activities used to describe investment activities are: Investment Credit Interest, LQ45 Index, while the variables that describe safe haven activities are inflation and exchange rates.

Stage II: Identify price movements. 
Identified by cross-correlation using optimal lag.

Stage III: Gold Prospect.

This stage is the forecasting stage of the price variable, whose value is then compared to find out how relevant the placement of gold is as a safe haven or diversifier investment.

\subsection{Data and data sources}

Data were collected from various sources (Table 1). The observed data period was 2018.1-2020.10 (34 monthly data). The data used in this study are as follows:

Table 1

Data and data sources

\begin{tabular}{|c|c|c|c|}
\hline NO. & Variables & Operational definition & Sources \\
\hline 1 & Gold Price (Gold) & Antam Gold Price per troy ounce & Inbizia \\
\hline 2 & $\begin{array}{l}\text { Investment Credit } \\
\text { Interest (Interest) }\end{array}$ & Commercial Bank investment loan interest rates & $\begin{array}{l}\text { Bank } \\
\text { Indonesia }\end{array}$ \\
\hline 3 & $\begin{array}{l}\text { Stock Price Index } \\
\text { (LQ45) }\end{array}$ & $\begin{array}{l}\text { Calculation of } 45 \text { stocks selected by performing several } \\
\text { selection criteria that are adjusted every six months }\end{array}$ & $\begin{array}{l}\text { Yahoo } \\
\text { finance }\end{array}$ \\
\hline 4 & $\begin{array}{l}\text { General Price Level } \\
\text { (Inflation) }\end{array}$ & Changes in the consumer price index & $\begin{array}{l}\text { Badan } \\
\text { Pusat } \\
\text { Statistik }\end{array}$ \\
\hline 5 & $\begin{array}{l}\text { Exchange Rate } \\
\text { Rp/USD (Exchange } \\
\text { Rate) }\end{array}$ & Rupiah value per US\$ 1 & $\begin{array}{l}\text { Badan } \\
\text { Pusat } \\
\text { Statistik }\end{array}$ \\
\hline
\end{tabular}

\subsection{Forecasting basic model}

There are various forecasting models that can be applied to time series data. There are at least four forecasting models (Eviews10, 2017; Agung, 2019), namely: (1) lag-variable basis, LV(p); (2) base Lag-Variable ARMA, $\operatorname{LVARMA}(p, q, r)$; (3) basis Threshold GARCH, T-GARCH(p,q,r); (4) Basis Instrumental Variables Model. This study uses the first basis, namely the lag variable (LV) by considering the simplicity of the model and data requirements. LV forecasting basis has two alternatives, namely: (a) a dynamic forecast, and (b) a static forecast. In general, the LV forecasting model is based on the following equation:

$$
Y_{t}=C(1)+C(2) Y_{t-1}+\cdots+C(p+1) Y_{t-p}+\mu_{t}
$$

The LV model does not consider errors in determining the forecast value, so $\mu_{t}=0$. The length of time-lag is an important factor in the forecasting model. The length of time-lag (t-p) that is carried out is basically a subjective consideration of the researcher. One of the considerations is to use optimum-lag. Some of the optimum lag indicators used are: Likelihood Ratio (LR), Final Prediction Error (FPE); and several Information Criteria models, consisting of Akaike (AIC), Schwarz (SC), and Hanan-Quinn (HQ).

A Dynamic Forecast vs A Static Forecast. The forecast values of the two models are based on a similar equation: 
$Y_{t+k}=C(1)+C(2) Y_{t-1}+\cdots+C(p+1) Y_{t+k-1}$

The two forecast models will have the same value in the initial period of their multi-period forecast. However, both will have differences in the continuation period. This difference will also appear when determining the bandwidth of the forecast. The dynamic forecast bandwidth will follow the error distribution that occurs dynamically by following the standard deviation pattern, as well as the static forecast will follow the error distribution statically.

Cross Correlation and Correlogram. Cross correlation is a method of measuring two variables to measure association relationships that occur at several specified time points. The two variables measured have different roles. The first variable acts as a driver variable while the second variable acts as an output. Mathematically, the cross correlation is not much different from the Pearson Product Moment correlation.

$$
\rho_{x y}(\ell)=\frac{\sum_{i=0}^{N-1}\left(x_{i}-\bar{x}\right) *\left(y_{i-\ell}-\bar{y}\right)}{\sqrt{\sum_{i=0}^{N-1}\left(x_{i}-\bar{x}\right)^{2}} \sqrt{\sum_{i=0}^{N-1}\left(y_{i-\ell}-\bar{y}\right)^{2}}}
$$

The degree of strength of the association between the two variables between $(-1.00)$ to $(+1.00)$ is called the correlation coefficient. The correlation coefficient is closer to the value of (1), the more it will show the identicalness of the two variables at a certain point in time. While a negative value leads to an understanding that $X$ leads $Y$ and if a positive value means $X$ lags $Y$. Investment analysts often use this method to understand the movement of these two types of investments in order to determine diversifiers investment.

Forecast Evaluation. Forecast Evaluation is a comparison of the forecast value with the actual value of the target value during the forecast period. The standard procedure used is to set aside some historical data to be used as a comparison sample for actual and estimated values. EViews allows the use of comparison samples to: (1) make statistical evaluations of estimates to provide a measure of forecast accuracy, and (2) perform combination tests to determine whether the combined mean of estimates outperforms single estimates.

The forecast evaluation model used is: (1) Root Mean Square Error (RMSE) and (2) Theil Inequality Coefficient (TIC). The RMSE is the standard deviation of the residuals, which reflects a measure of how far from the data points the regression line is. The RMSE is a measure of how spread out this residual is, or gives an explanation of how concentrated the data is around the line that best fits. The smaller (closer to zero) the better the forecast results. The RMSE formulation is as follows (Eviews10, p. I 398):

$$
\sqrt{\sum_{t=T+1}^{T+h}\left(g_{t}-y_{t}\right)^{2} / h}
$$

Theil Inequality Coefficient (TIC) otherwise known as Thiel's U, provides a measure of how well the time series of estimated values compare to the corresponding time series of observed values. Statistics measure the extent to which a time series $(\{X i\}, i=1,2,3, \ldots n)$ differs from one another $(\{Y i\}, i=1,2,3, \ldots n)$. Thiel's $U$ is calculated as: 


$\frac{\sqrt{\sum_{t=T+1}^{T+h}\left(y_{t}-y_{t}\right)^{2} / h}}{\sqrt{\sum_{t=T+1}^{T+h} y_{t}^{2} / h+\sqrt{\sum_{t=T+1}^{T+h} y_{t}^{2} / h}}}$

The smaller Theil value (the closer to zero) the better the forecast value.

\section{Result And Discussion}

The five variables used in this analysis are price variables that have three sizes. The interest rate and inflation variables have the form of a percentage (\%), the LQ45 variable has the form of an index, and the gold price and exchange rate variables have the form of money units. The form of this measure is important to be able to interpret descriptive statistics on it.

Interest rate, Gold Price, LQ45 and Inflation variables have a normal distribution because there is a tendency for the movement of these price variables to be driven by natural movements (according to market movements). Meanwhile, the exchange rate variable often contains an element of intervention from the monetary authority in responding to the natural movements of the foreign exchange market. Policy variables, such as the exchange rate, are very reasonable if they show abnormal symptoms. 
Table 2

Mean and data dispersion

\begin{tabular}{|lllllll|}
\hline & Mean & SD & Distribution & & \multirow{2}{*}{ Samples } \\
\cline { 5 - 6 } & & & Skewness & Kurtosis & JB (Prob) & \\
\hline Interest & 10.032 & 0.466 & -0.983 & 2.544 & $5.766(0.056)$ & 34 \\
\hline D(Intereset) & -0.044 & 0.078 & 0.250 & 4.677 & $4.211(0.122)$ & 33 \\
\hline Gold & 1461.317 & 232.310 & 0.829 & 2.524 & $4.217(0.121)$ & 34 \\
\hline D(Gold) & 16.238 & 52.113 & 1.196 & 4.489 & $10.911(0.004)$ & 33 \\
\hline LQ45 & 930.660 & 110.677 & -0.787 & 2.641 & $3.692(0.158)$ & 34 \\
\hline D(LQ45) & -9.553 & 51.915 & -1.345 & 5.463 & $18.293(0.000)$ & 33 \\
\hline Inflation & 0.199 & 0.237 & 0.289 & 2.521 & $0.798(0.671)$ & 34 \\
\hline D(Inflation) & -0.017 & 0.245 & 0.053 & 2.105 & $1.117(0.572)$ & 33 \\
\hline Exchange Rate & 14356.62 & 548.458 & 1.445 & 6.583 & $30.023(0.000)$ & 34 \\
\hline D(Exchange Rate) & 38.697 & 523.786 & 1.418 & 9.723 & $73.217(0.000)$ & 33 \\
\hline Note: & & & & & & \\
\hline
\end{tabular}

Changes in variables, such as D(Gold), D(LQ45) and D(Exchange rate) show the distribution abnormality. The interpretation that can be pinned on this condition is the assumption that the three variables, the movement of which describes the speculative attitude of the holder. Between the minimum value of change, Dmin, and the maximum value of change, Dmax, there is a high deviation. When deviations occur in the change data, it can be interpreted as a speculative trait.

Cross-correlation analysis. Cross-correlation analysis is used to determine the correlation between two variables by considering the movement for a certain range. In this case, the time range used is 16 lags following the default program. From the calculation results can be described:

Cross-correlation $\mathbf{d}($ Gold) $\leftrightarrow$ Interest. The interest variable is considered as a representation of the movement of the real sector. Assuming that the owner of the asset will place his asset with two alternatives. The first alternative, assets are placed in a form that is able to provide profits, or diversifier investment. The second alternative, assets are placed in haven positions when profits cannot be achieved. The interest variable describes the investment situation in the real sector. Decisions about interest rates must be based on the market. The higher interest rates can be caused by a high demand for credit. Because the real sector promises big profits, the demand for credit will increase which will result in an increase in credit prices (interest rate).

From the correlation results, in general, it was noted that $\mathrm{r}(\mathrm{d}(\mathrm{gold})$, interest $)=-0.229$ (prob. $=0.20)$. This means that there is a tendency for the gold-interest relationship as a safe haven or hedge. These results are supported by cross- 
correlation results: Lag-0 to lag-4 r(d(gold), interest) $<0$ and lag-5 to lag-16 r(d(gold), interest) $>0$, with correlation which tends not to be statistically significant, it is more directed to safe haven.

These results are supported by Flavin et.al. (2014) and Baur and Lucey (2010), that gold has a tendency as a safety asset when the economy is in a turnmoil situation.

Cross-correlation d(Gold) $\leftrightarrow \mathrm{d}(\mathrm{LQ45})$. The LQ45 variable represents asset development efforts through the capital market. From the correlation results, in general, it was noted that $r(d(g o l d), d(L Q 45))=0.234$ (prob.=0.19). This means that there is a tendency for gold-LQ45 to be a safe haven. From the results of cross-correlation: lag-0 to lag-2 $\mathrm{r}(\mathrm{d}($ gold $), \mathrm{LQ} 45)>0$ and lag-3 to lag-5 $\mathrm{r}(\mathrm{d}($ gold $), \mathrm{LQ} 45)<0$. With a correlation that tends to not statistically significant, the gold-LQ45 relationship is more towards safe havens.

This finding is different from Robiyanto (2018) who relates it to bonds, that gold is an investment tool because bonds themselves have dual benefits, firstly as an investment tool, secondly, corporate bonds and government bonds, have a tendency to always follow the movement of the driving factors, such as interest rates. or the exchange rate, so bondholders do not need to place gold as a safe haven. Gold will be used as a diversifier investment.

Cross-correlation d(Gold) $\leftrightarrow$ Inflation. From the correlation results, in general, it is recorded that $\mathrm{r}(\mathrm{d}(\mathrm{gold})$, inflation) $=$ 0.119 (prob. $=0.51$ ) meaning, there is a tendency for the gold-inflation relationship to move positively towards inflation, which indicates that gold can be relied on as a wealth guard. From the results of cross-correlation: lag-0 to lag-2 $\mathrm{r}(\mathrm{d}$ (gold), inflation) > 0; lag-3 to lag-5 $\mathrm{r}(\mathrm{d}$ (gold), inflation) $<0$ and the next lag tends to be positive; $r(\mathrm{~d}(\mathrm{gold})$, inflation) $>0$. This confirms that gold is a safety tool against a decline in the value of money with a relative increase in the general price level.

Cross-correlation $\mathrm{d}($ Gold $) \leftrightarrow \mathrm{d}($ Exchange Rate). From the correlation results, in general, it was noted that $r(d($ gold $), d($ Exchange $))=-0.117$ (prob.=0.52). This shows that the gold-exchange relationship tends to be a safe haven. From the results of cross-correlation: lag- 0 to lag-3 r(d(gold), exchange rate) $<0$ and lag-4 to lag-5 r(d(gold), exchange rate) $>0$, with a correlation that tends to not statistically significant, so it is more directed to a safe haven.

This is in line with the research results of Shakil, et.al. (2017) which shows that gold is a good safety tool for fluctuations in the IDR/USD exchange rate.

Forecasting. This forecasting stage considers the optimum lag which is calculated based on the Vector Auto Regressive (VAR) analysis. The results of the lag measurement that will provide the optimum lag are as follows: 
Table 3

Optimum lag

\begin{tabular}{|llllll|}
\hline & LR & FPE & AIC & SC & HQ \\
\hline Gold (Lag-1) & $78.72638 *$ & $3203.547 *$ & $10.90965 *$ & $11.00480 *$ & $10.93874 *$ \\
\hline Interest (Lag-1) & $94.23430 *$ & 0.006874 & -2.142399 & $-2.047241 *$ & $-2.113308 *$ \\
\hline LQ45 (Lag-1) & $39.34905 *$ & $2995.821 *$ & $10.84261 *$ & $10.93776 *$ & $10.87170 *$ \\
\hline Inflation (lag-3) & 2.146826 & $0.038417 *$ & $-0.423334 *$ & -0.233019 & $-0.365153^{*}$ \\
\hline Exchange Rate (lag-1) & 5.393336 * & $252117.4 *$ & $15.27528 *$ & $15.37044 *$ & $15.30437 *$ \\
\hline * indicates lag order selected by the criterion & & & \\
\hline
\end{tabular}

The next stage is to choose the most accurate forecasting method, based on the least square method. The choice is between the dynamic method and the static method, the choice of which is determined by two main indicators, namely: Root Mean Square Error (RMSE) and Theil's Inequality Coefficient (TIC). The calculation results are as follows:

Table 4

Forecast evaluation

\begin{tabular}{|lllllllllll|}
\hline \multirow{2}{*}{ EVALUASI } & EMAS & \multicolumn{3}{c}{ BUNGA } & \multicolumn{2}{c}{ LQ45 } & \multicolumn{2}{cl}{ INFLASI } & \multicolumn{2}{c|}{ KURS } \\
\cline { 2 - 11 } & DF & SF & DF & SF & DF & SF & DF & SF & DF & SF \\
\hline RMSE & 206.059 & 51.019 & 0.251 & 0.074 & 97.007 & 49.250 & 0.237 & 0.175 & 496.156 & 441.755 \\
TIC & 0.065 & 0.017 & 0.013 & 0.004 & 0.053 & 0.026 & 0.481 & 0.324 & 0.017 & 0.015 \\
\hline
\end{tabular}

With the evaluation results, the forecasting model is based on the selected equation, namely:

Model-1: $\quad$ Gold $_{t}=-20.159+1.025$ Gold $_{t-1} ; R^{2}=0.95$

Model-2: $\quad$ Interest $_{t}=-0.487+1.044$ Interest $_{t-1} ; R^{2}=0.97$

Model-3: $\quad L Q 45_{t}=109.253+0.873 L Q 45_{t-1} ; R^{2}=0.78$

Model-4: $\quad$ Inflation $_{t}=0.189+0.587$ Inflation $_{t-1}-0.292$ Inflation $_{t-2}-$

0.258 Inflation $_{t-3} ; R^{2}=0.48$

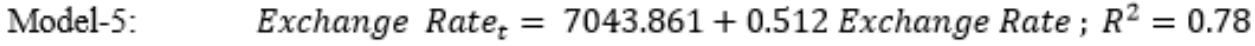

Forecasting of several price variables analyzed is carried out for the purpose of seeing in the next year, how the nature of the movement of gold price expectations on the other four variables. The correlation that occurs between the gold expectation variable and other expectation variables is as follows:

Correlation (goldsf-interestsf) $=-0.99$; Correlation (Goldsf-inflationsf) $=-0.44$; Correlation (Goldsf-Exchange ratesf) $=$ -0.69; Correlation (Goldsf-LQ45sf) $=0.96$. The correlation value indicates that the relationship between the gold priceinterest and gold-exchange rate in the future is a strong complementarity, while the relationship between the gold price and the LQ45 variable is a very strong substitution or diversification.

\section{Conclusions}


The results of the cross-correlation calculation between gold and investment credit interest rates, the LQ 45 index, inflation and exchange rates have a low correlation in that period (2018-2020). This means that gold is more of a safe haven than an investment diversifier, meaning that gold is an asset that is able to maintain the value it contains, not easy to depreciate.

For gold price expectations for the next year, based on the correlation results, it shows that the relationship between gold prices - interest rates and gold prices - exchange rates is strong complementary, while the relationship between gold prices and the LQ45 variable is very strong substitution or diversification.

For now, use gold as a haven. For the next year, gold assets can be replaced with investments in the real sector or can replace gold with deposits in the form of US\$ currency or short-term securities.

\section{Declarations}

\section{Acknowledgements}

We would like to thank the Research Centre (LPPM) of Stikubank University Semarang, Indonesia for its support. We would also like to thank our lecturers from the Faculty of Economics and Business, Stikubank University, Semarang, Indonesia, for their useful discussions and contributions.

\section{Authors' contributions}

All authors have developed research ideas and concepts together. All authors have also worked on analyzing, calculating, and writing parts of the manuscript. All authors read and approved the final manuscript.

\section{Funding}

This research is an independent research that is not funded by any party.

\section{Availability of data and materials}

The data used for this study are publicly available and are described in section 3 of the methodology.

\section{Competing interests}

The authors state that they have no competing interests.

\section{Author details}

${ }^{1}$ Postgraduate Program, Faculty of Economics and Business, Stikubank University, Semarang, Indonesia. ${ }^{2}$ Management Department, Faculty of Economics and Business, Stikubank University, Semarang, Indonesia.

\section{References}

1. Agha, S.E., Saafi, A.R., Qayoom, O.A. (2015). Gold investment fromi islamic perspective: The case of Malaysia. International Journal of Economics and Finance, 7(5).

2. Agung, I Ng. (2019). Advance time seriesdData analysis. John Wiley \& Sons. 
3. Amaresh. D. (2015). Money as a medium of exchange: Then and now: Can technology be a facilitator of exchange. Global Journal of Management and Business Research: economics and Commerce, 15(11).

4. Badan Pusat Statistik. (2020). Indikator Ekonomi Indonesia, berbagai terbitan. www.bps.go.id

5. Bank Indonesia. (2020). Statistik ekonomi dan keuangan Indonesia berbagai terbitan. Bank Indonesia: www.bi.go.id

6. Baur, D.G., Lucey, B.M. (2010). Is gold a hedge or a safe haven? An analysis of stocks, bonds and gold. The Financial Review, 45, .217-229

7. Clara, D.C., Inghelbrecht, K. (2019). Is Gold Still a Safe Haven. A dissertation submitted to Ghent University in partial fulfilment of the requirements for the degree of Master of Science in Business Administration: Finance and risk Academic year: 2018 - 2019

8. Dornbusch, R., Fischer, S., Startz, R. (2008). Macroeconomics $10^{\text {th }}$ Edition, McGraw-Hill.

9. Eviews 10 User's Guide II

10. Faugere, C., Erlach, J.V. (2006). The price of gold: A global required yield theory. Journal Investing, 14, 99-111.

11. Flavin, T. J., Morley, C.E., Panopoulou, E. (2014). Identifying safe haven assets for equity investors through an analysis of the stability of shock transmission. Journal of International Financial Markets, Institutions and Money, 33, 137-154.

12. Frederic, M.S. (2019). The economics of money, banking and financial market. Twelfth Edition. Pearson.

13. Ghazali, M.H., Lean, H.H., Bahari, Z. (2013). Is gold a hedge or a safe haven? An empirical evidence of gold and stocks in Malaysia. International Journal of Business and Society, 14(3), 428-443.

14. Ibrahim, M. H., Baharom, A.H. (2012). The role of gold in financial market: A Malaysian perspective. Economic Computation and Economic Cybernetics Studies and Research.

15. Inbizia. (2020). Informasi Bisnis Indonesia. http://www.inbizia.com

16. Kovinski, I., (2014). Gold as a safe haven or speculative investment. Theses Master in Finance Instituto Universitário de Lisboa

17. Lucey, B.M., Tully, E., Poti, V. (2006). International portfolio formation, skewness and the role of gold. Frontier in Finance and Economics, 3, 1-17

18. Nelly, F. (2017). The role of gold in an investment portfolio an empirical study on diversification benefits of gold from the perspective of Swdish investors. UMEA Universitet.

19. O'Connor, F.A., Lucey, B.M., Batten, J.A., Baur, D.G. (2015). The financial economics of gold: A survey. MPRA paper No.65484 (8 July 2015).

20. Oliver, B. (2017). Macroeconomics-global edition. Seventh Edition. Pearson Education.

21. Parkin, M., Bade, R. (1992). Macroeconomics. Prentice-Hall International, Inc.

22. Ritholdz, B. (2016). Is Gold A Store of value or an investment?

23. Ritholtz, B. (2016). Is Gold A Store of value or an invesment? https://ritholtz.Com/author/ritholtz.

24. Robiyanto. (2018). Gold vs bonds: What is the safe haven for the Indonesian and Malaysia capital market? Gadjah Mada International Journal of Business, 20(3), 277-302.

25. Shakil, M.H., et.al., 2017. Is gold a hedge or a safe haven? An application of ARDL approach. Journal of Economics, Finance and Administrative Science, 23(44), 66-76.

26. Toraman, C., Basarir, C., Bayramoglu, M.F. (2011). Determination of factor affecting the price of gold: A study of MGARCH model. Business and Economics Research Journal, 2(4), 37-50.

Page $11 / 13$ 


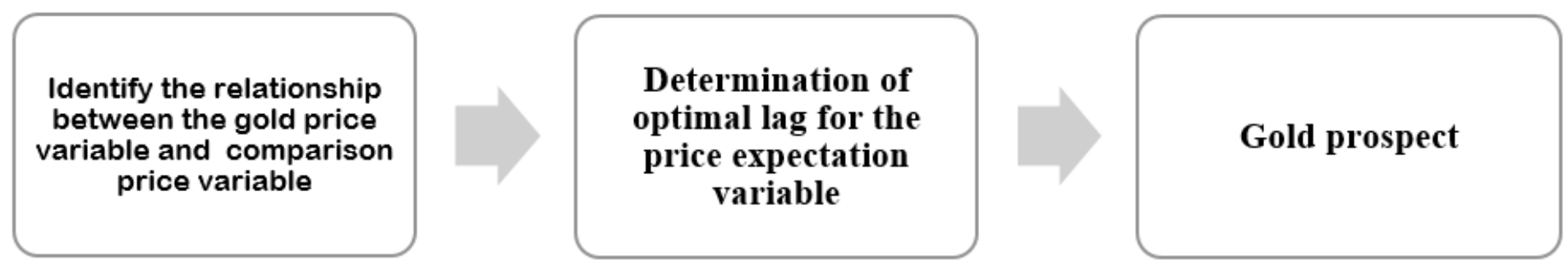

Figure 1

Analysis flowchart

Date: $01 / 25 / 21$ Time: $22: 40$

Sample: 2018M012020M 10

Included observations: 33

Correlations are asymptotically consistent approximations

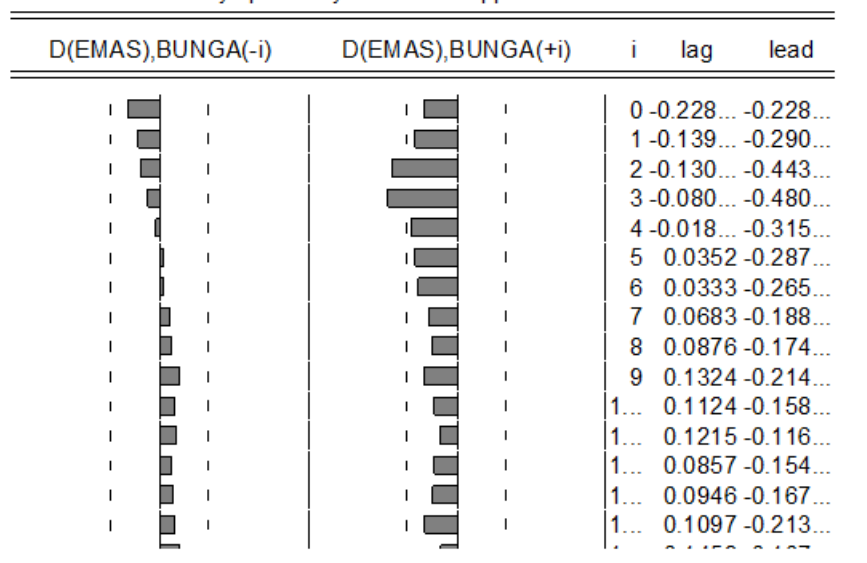

(a)

\begin{tabular}{|c|c|c|c|}
\hline \multicolumn{4}{|c|}{$\begin{array}{l}\text { Date: } 01 / 25 / 21 \text { Time: } 22: 41 \\
\text { Sample: } 2018 \mathrm{M} 012020 \mathrm{M} 10 \\
\text { Included observations: } 33 \\
\text { Correlations are asymptotically consistent approximations }\end{array}$} \\
\hline $\mathrm{D}$ (EM AS),D(LQ45)(-i) & $\mathrm{D}(\mathrm{EM} A S), \mathrm{D}(\mathrm{LQ} 45)(+\mathrm{i})$ & lag & lead \\
\hline$\sqsupset$ । & 1 & $0 \quad 0.2341$ & 0.2341 \\
\hline । & 1 & 10.0147 & 0.0125 \\
\hline 1 & I & $2-0.017 \ldots-$ & $-0.251 \ldots$ \\
\hline 1 & 1 & $3-0.023 \ldots$ & 0.0330 \\
\hline$\square$ & 1 & $4-0.387 \ldots$ & 0.2412 \\
\hline 1 & $1 \square$ & $5-0.034 \ldots-$ & $-0.116 \ldots$ \\
\hline$\square \quad$ । & 1 & $6 \quad 0.1424$ & 0.1341 \\
\hline$\square$ & $\square$ & $70.3620-$ & $-0.321 \ldots$ \\
\hline 1 & $1 \square$ & $8-0.038 \ldots-$ & $-0.190 \ldots$ \\
\hline 1 & $\square$ & $90.0224-$ & $-0.314 \ldots$ \\
\hline 15 & $\square 1$ & $1 \ldots-0.072 \ldots$ & 0.1572 \\
\hline 17 & ]$\quad 1$ & $1 \ldots 0.0137$ & 0.0889 \\
\hline 1 口 । & $\square$ । & 1... 0.1182 & 0.2132 \\
\hline 1 $\square$ । & $1 \square$ & 1... 0.2002 - & $-0.133 \ldots$ \\
\hline 1 $\square$ । & । & $1 \ldots-0.132 \ldots$ & 0.0172 \\
\hline
\end{tabular}

(b)

Date: $01 / 25 / 21$ Time: $22: 42$

Sample: 2018M01 2020M 10

Included observations: 33

Correlations are asymptotically consistent approximations

\begin{tabular}{|c|c|c|c|c|c|}
\hline D(EMAS),INFLASI(-i) & $\mathrm{D}(\mathrm{EMAS}), \mathrm{INF}$ & $\operatorname{ASI}(+\mathrm{i})$ & i & lag & lead \\
\hline 口 & 口 & 1 & 0 & 0.1198 & 0.1198 \\
\hline ו & $1 \square$ & 1 & 1 & 0.2647 & $-0.230 \ldots$ \\
\hline$\nabla_{1}$ & $1 \square$ & 1 & 2 & 0.2110 & $-0.283 \ldots$ \\
\hline 1 - 1 & $\sqsubset$ & 1 & & $-0.083 \ldots$ & $-0.341 \ldots$ \\
\hline $1 \square$ & $1 \square$ & 1 & & $-0.218 \ldots$ & -0.169 . \\
\hline 1 & 10 & 1 & & $-0.033 \ldots$ & 0.0352 \\
\hline । $\square$ । & G & 1 & 6 & 0.2067 & 0.0985 \\
\hline$\square$ । & b & 1 & 7 & 0.1888 & 0.0424 \\
\hline ] 1 & & 1 & 8 & 0.1143. & $-0.083 \ldots$ \\
\hline $1 \square \quad$ & $1 \square$ & 1 & & $-0.258 \ldots$ & $-0.235 \ldots$ \\
\hline$\square$ & 1 口 & 1 & $1 \ldots$ & $-0.289 \ldots$ & $-0.168 \ldots$ \\
\hline 10 & $1 \square$ & 1 & $1 \ldots$ & $-0.031 \ldots$ & $-0.218 \ldots$ \\
\hline $1 \quad \square$ & 10 & 1 & $1 \ldots$ & 0.4106 & $-0.041 \ldots$ \\
\hline$\square$ & 10 & 1 & $1 \ldots$ & 0.3518 & $-0.097 \ldots$ \\
\hline I & [ & 1 & $1 \ldots$ & 0.2810 & $-0.056 \ldots$ \\
\hline 111 & $1 \pi$ & 1 & $q_{1}$ & ก กก८. & - 01.9 \\
\hline
\end{tabular}

(c)

Date: 01/25/21 Time: 22:38

Sample: 2018M01 2020M10

Included observations: 33

Correlations are asymptotically consistent approximations

\begin{tabular}{|c|c|c|c|c|}
\hline \multicolumn{2}{|c|}{$\mathrm{D}(\mathrm{EMAS}), \mathrm{D}(\mathrm{KURS})(-\mathrm{i})$} & $\mathrm{D}(\mathrm{EMAS}), \mathrm{D}(\mathrm{KURS})(+\mathrm{i})$ & lag & lead \\
\hline 1 디 & 1 & 1 & $0-0.117 \ldots$ & $-0.117 \ldots$ \\
\hline 1 & 1 & $1 \square$ & $1-0.038 \ldots$ & $-0.166 \ldots$ \\
\hline $1 \square$ & 1 & 1 & $2-0.131 \ldots$ & 0.2009 \\
\hline $1 \square$ & 1 & 1 & $3-0.133 \ldots$ & $-0.022 \ldots$ \\
\hline & & 1 & $\begin{array}{ll}4 & 0.4877\end{array}$ & $-0.228 \ldots$ \\
\hline & 1 & 1 & $\begin{array}{ll}5 & 0.1928\end{array}$ & 0.0091 \\
\hline $1 \square$ & 1 & 1 & $6-0.242 \ldots$ & $-0.047 \ldots$ \\
\hline$\square$ & 1 & $\square$ & $7-0.372 \ldots$ & 0.3334 \\
\hline 10 & I & 1 & 80.0723 & 0.0078 \\
\hline 1 디 & 1 & 1 & $9-0.097 \ldots$ & 0.2939 \\
\hline $1 口$ & I & $\square$ & 1... 0.1131 & $-0.280 \ldots$ \\
\hline 1 & 1 & 1 प & $\begin{array}{ll}1 \ldots & 0.0278\end{array}$ & $-0.058 \ldots$ \\
\hline & 1 & 1 口 & 1... 0.0640 & $-0.132 \ldots$ \\
\hline 1 口 & 1 & । $\quad \square$ । & 1. $\ldots-0.122 \ldots$ & 0.1620 \\
\hline 17 & I & $6 \quad 1$ & $\left.\right|_{1} \quad \mathrm{n} \cap \cap 20$ & ก ก787 \\
\hline
\end{tabular}


Figure 2

Cross correlation and correlogram 